\title{
Linguistic analysis of reading and teaching reading by literary translation
}

\section{Madina BURANOVA ${ }^{1}$}

Samarkand State Institute of Foreign Languages

\section{ARTICLE INFO}

\section{Article history:}

Received September 2020

Received in revised form 15

September 2020

Accepted 25 September

2020

Available online

1 October 2020

\section{Keywords:}

Ilya Frank's reading method

Literary translation

Learning foreign languages

Language skills

Parallel texts

\begin{abstract}
Today there are various methods of teaching a foreign language. All teaching methods are designed at different times to provide the need for a wide range of people to master a foreign language. Progress and fundamental changes in language learning methods are associated with innovations in the field of psychology of an individual and a group. The psychological factor of learning foreign languages is moving forward. Among the many methods of learning languages, one of the most popular was developed by Ilya Frank. The Frank reading method helps passively master a non-native language in a short period of time. This particular article deals with new method of teaching reading English based on Ilya Frank's methodology.
\end{abstract}

2181-1415/C 2020 in Science LLC.

This is an open access article under the Attribution 4.0 International (CC BY 4.0) license (https://creativecommons.org/licenses/by/4.0/deed.ru)

\section{Ўқишни лингвистик тахлил қилиш ва сўзма-сўз таржимани ўқишга ўргатиш}

\author{
Калит суцзлар: \\ Иля Франкнинг ўқиш \\ техникаси \\ Бадиий таржима \\ Чет тилларни ўрганиш \\ Тилни билиш \\ Параллель матнлар
}

\begin{abstract}
АННОТАЦИЯ
Бугунги кунда чет тилини ўқитишнинг турли хил усуллари мавжуд бўлиб, улар турли даврларда ишлаб чиқилган ва ўқувчиларнинг чет тилини ўзлаштиришга бўлган талабини қондириш учун измат қилиб келмоқда. Тилни ўрганиш услубидаги тараққиёт ва туб ўзгаришлар инсон ва омма психологияси сохасидаги янгиликлар билан чамбарчас боғлиқ. Чет тилларни ўрганишнинг психологик омилини ўрганишга кўпроқ эътибор берилмоқда. Тилларни ўрганишнинг кўплаб усуллари орасида энг
\end{abstract}

\footnotetext{
${ }^{1}$ Senior teacher of Samarkand State Institute of Foreign Languages Samarkand, Uzbekistan e-mail: madinaburanova82@gmail.com
} 
машхурларидан бири Иля Франк томонидан ишлаб чиқилган. Очиқ (овоз чиқариб) ўқиш усули қисқа вақт ичида чет тилини пассив равишда ўзлаштиришга ёрдам беради. Ушбу мақолада Иля Франк методологиясига асосланган инглиз тилида ўқишни ўргатишнинг янги усули мухокама қилинади.

\section{Лингвистический анализ чтения и обучение чтению художественным переводом.}

\section{Ключевые слова:}

Методика чтения Ильи Франка

Художественный перевод Изучение иностранных языков

Языковые навыки

Параллельные тексты

\begin{abstract}
АННОТАЦИЯ
Сегодня существуют различные методики обучения иностранному языку. Все методы обучения разработаны в разное время, для обеспечения потребности людей в овладении иностранным языком. Тем не менее, прогресс и фундаментальные изменения в методах изучения языка связаны с инновациями в области психологии человека и группы. Психологический фактор изучения иностранных языков продвигается вперед. Среди множества методов изучения языков один из самых популярных разработал Илья Франк. Метод откровенного чтения помогает пассивно освоить неродной язык за короткий промежуток времени. В данной статье рассматривается новый метод обучения чтению английского языка, основанный на методике Ильи Франка.
\end{abstract}

Reading books is not just a pleasant way of spending time, but also one of the best ways to broaden your horizons, enrich your speech, and shape your worldview.

There are very few people who are unable to learn the language physically. The fact is that many people have convinced themselves that learning a language is a very complicated matter. They live with it all their lives, creating additional barriers for themselves.

There are many methods of teaching a foreign language, and today everyone can choose a convenient format for themselves. As a rule, all of them are based on a consistent study of the structure of the language, the rules of grammar, memorization of words and development of speaking skills. Ilya Frank, a Russian philologist and polyglot, has developed and launched to the masses an innovative approach to the development of foreign languages an absolutely unique technique. He himself calls it the passive development of a foreign language, and the technology is based on parallel reading. With this approach, it is quite possible to master one or even several foreign languages. Let us examine in more detail how this works.

\section{MATERIALS AND METHODS}

First of all, the reader should read the disassembled part of the text, carefully understanding the translation. Sometimes several translations are given to make it easier for the reader to understand the exact meaning of this phrase. After this part of the text is 
worked out, it is worth reading the original. This makes it possible to consolidate the material covered. Repeat the same steps are not necessary, you can go to the next passage.

In order to master a foreign language by this method, special texts will be required. How do they differ from ordinary literature?

As a rule, such texts are divided into semantic parts. Each passage is written with small comments on the translation after each key phrase. Thus, the reader does not need to be distracted from reading and turn to a dictionary or other sources for translation. Such an approach greatly simplifies perception and contributes to the quickest memorization of what is written. After translation, the same text is given in the original without footnotes.

In addition to translation, Ilya Frank, whose reading method is aimed at memorizing new words and expressions, provided for the transcription of written words. And in books, transcription is written with the sounds of the language in which the book is written. Without a doubt, it helps not only to remember a new word, but also its correct pronunciation.

The peculiarity of the perception of such a text is the invisible for the reader to postpone in memory the main words and phrases. While reading these books, there is no need to be distracted from the process, look for the right word in the dictionary or do some other unnecessary work. Everything that the reader needs is in front of his eyes. Using the method of Ilya Frank, English can be learned many times faster.

At the present time it is fairly easy to find all kinds of textbooks and various adapted literature in different languages. One of the best ways of teaching was offered by Ilya Frank. The method of reading offered in his books makes it much easier to learn a foreign language. The principle is as follows:

- A short excerpt is given with a literal translation in parentheses, as well as lexicogrammatical comments, if necessary for a better understanding;

- Then the same fragment is given without translation.

As Ilya Frank says, the method of reading helps to learn the language faster due to the frequent occurrence of the words and the habituation to the grammatical system.

After several such sentences, the same passage in the original and without marks follows, i.e. unadapted text

Example:

A spoon was attached to the neck of the bottle (ложка была прикреплена к горлышку бутылки), and into this Mary Poppins poured a dark crimson fluid (и в нее Мэри Поппинс налила темную малиновую жидкость; crimson - малиновый, темно-красный, кармазинный).

"Is that your medicine (это Ваше лекарство)? enquired Michael, looking very interested (спросил Майкл, выглядя заинтересованным/любопытствующим).

“No, yours (нет, твое)," said Mary Poppins (произнесла Мэри Поппинс), holding out the spoon to him (протягивая ему ложку). Michael stared (Майкл пристально /на нее/ посмотрел/уставился). He wrinkled up his nose (он сморщил нос). He began to protest (он начал возражать). 

буду)!"

“I don't want it (я не хочу это). I don't need it (мне это не нужно). I won't (я не

A spoon was attached to the neck of the bottle, and into this Mary Poppins poured a dark crimson fluid.

"Is that your medicine?" enquired Michael, looking very interested.

"No, yours," said Mary Poppins, holding out the spoon to him. Michael stared. He wrinkled up his nose. He began to protest.

"I don't want it. I don't need it. I won't!"

Having dealt with the structure of the text, you should go directly to the way of learning the language. The method of reading Ilya Frank, the English language is studied or any other, has its own characteristics.

Regularity is one of the important components of success. Even 30 minutes of training a day is more effective than a three-hour lesson once a week. However, as the author of the idea, Ilya Frank, advises, the method of reading will be more effective with daily two-hour classes. Thus, you can increase your vocabulary to 1000 within a month. When you start reading, you should be patient and tune in to regular classes. If you allow long intervals, loose knowledge can be lost. Learning a foreign language is like an ice slide, which you need to climb quickly, otherwise you risk falling down. Such a vivid comparison leads the author of the above idea Ilya Frank. The reading method developed by him will help you quickly master any language.

\section{RESULTS AND ITS DISCUSSION}

Pros and cons of the method of teaching reading Ilya Frank in the study of foreign languages. To an untrained person, the text may at first seem too complicated. However, as a rule, such books are divided into levels by which you can choose the right one. Moreover, the texts are provided with almost literal translation, therefore problems with understanding should not arise. Often, as time passes, the student does not need to refer to the adapted text at all, he can read without translation, and then verify the correctness of the read with the help of the previous part of the text.

Pros and cons of the method of teaching reading Ilya Frank in the study of foreign languages on September 28, 2019:

\section{5 minutes}

1.3 thousand views. Unique visitors to the page.

872 readings, $66 \%$. Users who read to the end.

2.5 minutes The average read time for a publication.

Everyone who studies foreign languages knows how laborious and endless the process is. It often happens that despite all efforts, progress is almost imperceptible. Now many different methods of studying foreign languages are offered, the authors of which claim that with their help the language can be learned quickly, easily and almost without stress.

\section{CONCLUSION}

This method shows excellent results when combined with conversational practice. However, it can be used separately. This method is aimed at memorizing words and 
stable expressions while reading. With it, you can learn to perceive written texts and even learn simple fiction in a short time.

In addition, according to Illya Frank himself, the method makes it possible to study anywhere and at any time. The book can be read in public transport, in traffic jams, on a break, on vacation and so on. After all, there is no need to carry specialized literature or stock up on additional equipment.

This method of learning the language can be useful to anyone who decides to really seriously approach the task set. However, it is possible that for qualitative knowledge more effort will be needed, so this method is rather suitable as an additional to others. These can be courses and live communication (preferably with native speakers). However, there is no doubt that the books that Ilya Frank offers for study, the method and such an innovative approach are guaranteed to help significantly increase the lexicon of any person.

The idea of passive learning is far from perfect. After all, in order to master something, it is necessary to make certain efforts. Nevertheless, one of the best options for implementing this idea is the method of reading Ilya Frank. Italian, Spanish, English or German - no matter which language you choose, the above technique will save time and succeed.

\section{References}

1. Alexander Dragunkin. [Electronic resource] - Access mode: http://www.dragunkin.ru. - Date of access: 09/26/2019.

2. Baryshnikov, N.V. Features of intercultural communication with imperfect knowledge of a foreign language / N.V. Baryshnikov // Teaching of intercultural communication in various conditions. - Pyatigorsk, 2000.

3. The best methods of learning English. [Electronic resource] - Access mode: https://www.englishdom.com/blog/luchshie-metodiki-izucheniyaanglijskogo. - Date of access: 09/26/2019.

4. Shekhter, I. Yu. Living language / I.Yu. Shekhter. - M.: Rector, 2005.

5. Myasishcheva O.N. Active teaching methods in English lessons http://nsportal.ru/shkola/inostrannye-yazyki

6. Website: EN Touch: Methods of learning English https://entouch.ru/stati/metodiki-izucheniya-angliyskogo-yazyka

7. A. Dragunkin, Universal English textbook. New approach http://dragunkin.ru

8. Website: Lifehacker, 70 Ways to Improve Your English. https://lifehacker.ru/2014/05/26/70-sposobov-uluchshit-svoj-anglijskij 